\title{
A Study on User-Oriented and Intelligent Service Design in Sustainable Computing: A Case of Shipbuilding Industry Safety
}

\author{
Taehee Joe ${ }^{1}$ and Hangbae Chang ${ }^{2, *}$ \\ 1 Ahnlab Inc., Seoul 13493, Korea; taehee.joe@ahnlab.com \\ 2 Department of Industrial Security, Chung-Ang University, Seoul 06911, Korea \\ * Correspondence: hbchang@cau.ac.kr \\ Academic Editors: Seungmin Rho, Naveen Chilamkurti and Ka Lok Man \\ Received: 30 January 2017; Accepted: 29 March 2017; Published: 4 April 2017
}

\begin{abstract}
Most business services based on Ubiquitous Computing are being designed with a sole focus on the technological sector, without considering business elements. In light of this trend, this study was intended to design a user-oriented u-Business service for preventing and promptly responding to industrial disasters at shipbuilding sites using a systematic methodology. Specifically, major danger elements of disasters in need of preferential preventive and responsive measures were derived as business opportunities unfulfilled by the current process, and then a u-Business service was developed to prevent/respond to such dangers. Statistical analysis was performed on the developed services according to evaluation models, and the final u-Business service was selected based on this analysis. Resources and information systems were designed to support the chosen service.
\end{abstract}

Keywords: Ubiquitous Computing; u-Business service; user-oriented service; shipbuilding industry

\section{Introduction}

Ubiquitous Computing allows people to freely connect to a network anytime and anywhere. In addition, Ubiquitous Computing can facilitate the establishment of sustainable computing. This environmental change provides companies with new business opportunities (u-Business services) [1-3]. However, most $\mathrm{u}$-Business services that are developed remain at an experimental (or trial) level, and incidences of advancing the service for commercialization (or industrialization) are rare [4-6]. This is because the design and development process focuses only on the technical aspects without considering the business aspects when developing u-Business services. Since services are developed based on technological facets without the collection of detailed user requirements, services that are irrelevant to creating business values are developed. Such u-Business service development methods have ultimately become an obstacle to the overall advancement and diffusion of the Ubiquitous Computing technology [6-10]. Therefore, this study intends to develop u-Business services that can be applied to actual businesses or industrial settings (a shipbuilding company or industry) according to the systematic business service development methodology which achieves business values.

\section{Literature Review on u-Business Service}

\section{1. u-Business Service Concept}

The Ubiquitous Computing concept was suggested by Mark Weiser in 1988. Since then, the ubiquitous is now not a simple concept establishment but is being increasingly materialized by being applied to numerous areas such as the practice and development of u-City, u-Government, 
$\mathrm{u}$-Health, $\mathrm{u}$-Transportation, $\mathrm{u}$-Education, $\mathrm{u}$-Distribution/Logistics, etc., and the Ubiquitous Computing is emerging as an important keyword that represents the current trend of IT industries [11,12]. The $\mathrm{u}$-Business is defined as a business system applied to a diversity of fields by using Ubiquitous Computing and networks to intellectualize things, terminals, goods inducing customers' business activities in the living environment, and devices or systems constructing business processes and by connecting them with networks $[11,13,14]$.

U-Business service is not an entirely new concept. Rather, it is an evolved or expanded e-business concept, which refers to the activities that create new values utilizing Ubiquitous Technology to improve existing business operations or design a new business model [15-17]. These u-Business services are partially similar to e-business services, but unlike the passive form of e-business services, $\mathrm{u}$-Business services offer autonomous business activities appropriate to the various circumstances (context) that an individual or organization faces [18-22]. Table 1 shows the results of a comparative analysis for current e-business and $u$-Business services that will be developed in the future $[23,24]$.

Table 1. Comparison between e-Business and u-Business service.

\begin{tabular}{cll}
\hline Items & \multicolumn{1}{c}{ e-Business Services } & \multicolumn{1}{c}{ u-Business Services } \\
\hline Main Technology & Wired internet, web technology, etc. & $\begin{array}{l}\text { Sensor network, wireless internet, } \\
\text { self-reasoning and learning skills } \\
\text { (Self Reasoning and Growing) }\end{array}$ \\
\hline Business Area & Limited business improvement & $\begin{array}{l}\text { Business process innovation, } \\
\text { can generate new business }\end{array}$ \\
\hline Business Activities & Passive (conscious) activities & $\begin{array}{l}\text { Context-based autonomous } \\
\text { activities }\end{array}$ \\
\hline Business Characteristics & $\begin{array}{l}\text { Expand offline business into } \\
\text { online business }\end{array}$ & $\begin{array}{l}\text { Integrate online and } \\
\text { offline business }\end{array}$ \\
\hline
\end{tabular}

\subsection{Analysis on Construction Processes in the Shipbuilding Industry}

The shipbuilding process, which begins from suggesting a ship's estimation to delivering the ship to the owner after completing its construction, is depicted as Figure 1.

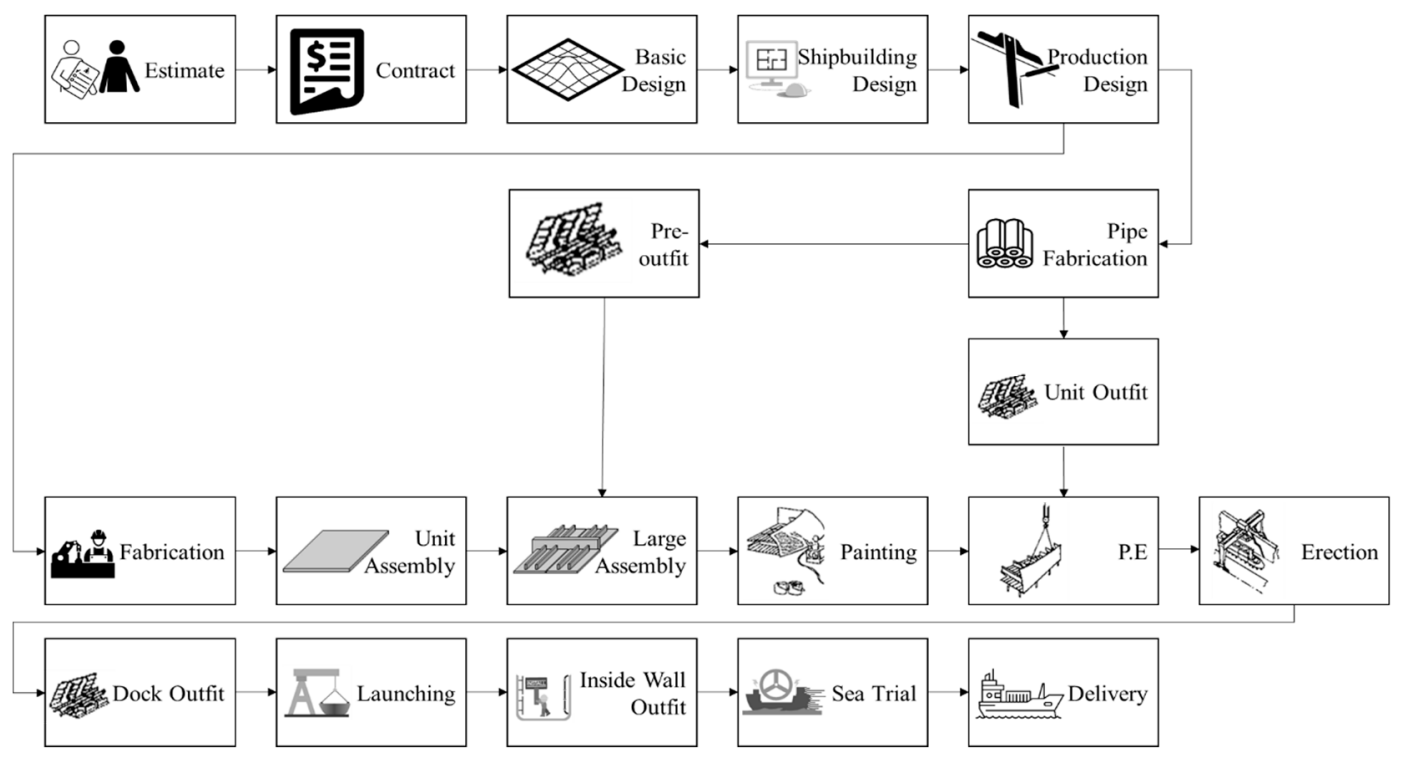

Figure 1. Shipbuilding Construction Process. 
The estimate and contract processes are carried out as follows. For ships, unlike general machines, automobiles, and electronic products that are already designed/produced for prospective customers, an order production system is applied once a customer orders a ship. Before submitting an official order, a ship owner determines principal features such as the type and size of the ship, the seaway and speed, and nationality and classification of the ship in advance, and requests information on the delivery time and estimated price of the ship to several shipyards. In return, shipyards provide detailed specification on the period of delivery and price to the ship owner after carefully considering factors such as their production capacity, the backlog of orders, etc. Once the construction contract is created between the ship owner and the shipyard, the shipyard designs basic and detailed features of the ship, entering a full-scale construction process.

The design (both basic and detailed) process goes through the following procedure. First and foremost, the shipyard designs the hull and outfit of the ship. The shipyard first draws out an optimum ship concept that satisfies the ship owner's requests and determines the ship's basic functions and the major materials and equipment that will be used. Then, the shipyard gives shape to the hull structure, arranges various devices including a main engine in the engine room, and specifically places outfitting equipment such as piping, electric devices, electric wires, deck, and sailing devices (basic design). If the drawings and specifications planned during this process are approved by the ship owner, drawings for fieldwork are prepared as a comprehensible design for the production site, and then the production information (e.g., shop drawing, setting drawing, design drawing, etc.) needed for the operation of field workers and machine tools (production design) are added to the overall design.

The structural steel warehousing (management) process goes through the following procedure. When the structural steel is delivered from a steel mill to the shipyard, it is piled up based on the product. The structural steel is unloaded, piled up, and sorted. Before processing the steel, preprocessing is conducted during which anti-corrosive paint is applied after removing the rust formed during the manufacturing process.

The processing of structural steel (marking, cutting, and forming (plate forming)) goes through the following procedures. The markings on the surface of structural steel indicate which product must be processed with lines and symbols. It goes through a cutting work that cuts out members as the marked shape and size. Typically, oxygen-acetylene mixture gas is used as a typical method, but lately plasma cutting is also being utilized. Afterwards, it bends (forms) a curved surface or curve by either applying mechanical force or by heating the steel sheet or steel.

The assembly (unit assembly, intermediate assembly, and large assembly) process goes through the following procedure. The hull's members produced in the processing plant are transferred to the assembly plant to go through the unit assembly process, where supplementary steel is affixed to the hull's internal structure. Then, the intermediate assembly follows, during which the ribs are affixed to the hull's shell plate. The structure then goes through the large assembly that forms a three-dimensional block to assemble the dock to an erectable size. The large assembled blocks are used to assemble a bigger block, which is erected before assembling the dock. This is called PE (pre-erection).

The erection process is carried out as follows. The final process of the hull's construction is to interconnect blocks that are transferred during the assembly process for building the berth or dock in order to shape the overall hull. Each block is formed as a ship on the dock at this stage, and placing the first block on the dock is called the keel laying. Because the hull presented in the design drawing must be completed, the hull dimensions must be precise. As the hull must be buoyant as a large structure in water, additional work is carried out on the dock in order to ensure safe and efficient workflow.

The (pre)outfit process is carried out as follows. The outfit work process involves various machines including a main engine needed for ship operation, electrical devices, piping work that allows connection to the system, provision of $\mathrm{crew}^{\prime} \mathrm{s}$ residence facility, etc. Formerly, the outfit work was carried out after the hull work (structural steel warehousing-structural steel processing-assembly-erection) was completed. However, nowadays the overall construction period 
and the amount of outfit work are reduced by simultaneously carrying out the block assembly and outfit work (pre-outfit).

The painting process is carried out as follows. The painting process prevents the ship from becoming rusty, and this process is carried out several times throughout the construction process. The rust is first removed before processing the structural steel and the primary painting is done. Then, the rust prevention process is carried out. When the block is finished, the painting process is carried out again, and the block is erected on the dock to complete the final welding work. The final painting process is conducted immediately before the launching process.

The launching and interior wall outfit process is carried out as follows. When the block is erected on the dock and the hull is completed welded, the dock is filled with seawater to set the ship afloat and go out to sea. This process is called the launching process. After launching, the interior wall outfit work finalized on the hull is moored alongside the pier.

The sea trial and delivery processes goes through the following procedure. Performance of various machinery, electronics and equipment installed on the ship is tested separately. When the equipment performance test that measures the ship's speed, fuel consumption and maneuvering performance, etc. is completed, the features are then demonstrated in the presence of the ship owner and classification society for checking ship's overall performance and verifying whether the design satisfies target performance. This stage is called the sea trial. Afterwards, it is set out to the outer harbor for a comprehensive sea trial, and only if it passes all the tests can the finalized ship be delivered to the ship owner.

\subsection{Features of the Shipbuilding Industry Sites}

The shipbuilding industry is uniquely an order-based custom-made industry unlike other manufacturing industries that primarily manufacture goods based on the planned production. In addition, because various functions and forms are demanded based on the ship owner's requirements, the product specification or construction process varies for each production, allowing only limited manufacture automation for small quantity batch products. In other words, it is a labor-intensive industry in which mass production is difficult. It is an industry with high availability because securing an extensive site and harbor is a top priority for producing ships, and an industry that has a great ripple effect on front industries such as shipping and fishing, and rear industries such as steel, machinery, electricity, electronics and chemical $[3,10]$.

The Table 2 shows that The shipbuilding industry's site has different characteristics from other manufacturing industries' sites due to its process features, and it is found that the type of accidents occurred is also very different from other manufacturing industries.

Table 2. Features of the Shipbuilding Industry Sites.

\begin{tabular}{ll}
\hline \multicolumn{1}{c}{ Features } & \multicolumn{1}{c}{ Content } \\
\hline $\begin{array}{l}\text { There are many movements between the } \\
\text { working places due to the works' } \\
\text { characteristics. }\end{array}$ & $\begin{array}{l}\text { There is high probability of human errors caused by repetitive } \\
\text { works such as installation of structures and equipment and } \\
\text { dismantling of the existing equipment due to frequent } \\
\text { movements of the processes followed by block assembly } \rightarrow \\
\text { outfit work } \rightarrow \text { painting work } \rightarrow \text { erection, etc. }\end{array}$ \\
\hline & $\begin{array}{l}\text { Because constructing ships are assembled with large steel } \\
\text { structures, the height of working places is from } 2 \mathrm{~m} \text { to } 10 \mathrm{~m} \text { or } \\
\text { more, many works are done in elevated places, and it is highly } \\
\text { There are always elevated working places. }\end{array}$ \\
& $\begin{array}{l}\text { likely that a series of accidents take place due to a drop and } \\
\text { falling objects, so it is more fatal than common accidents. }\end{array}$ \\
\hline
\end{tabular}


Table 2. Cont.

\begin{tabular}{ll}
\hline \multicolumn{1}{c}{ Features } & \multicolumn{1}{c}{ Content } \\
\hline $\begin{array}{l}\text { There are many narrow enclosed spaces } \\
\text { because of its structure. }\end{array}$ & $\begin{array}{l}\text { There is always potential dangerousness of serious accidents and } \\
\text { suffocation possibly caused by the inadequacy of ventilation } \\
\text { facilities due to excessive enclosed areas. }\end{array}$ \\
\hline $\begin{array}{l}\text { It is difficult to control such as adjustment of } \\
\text { order between works. }\end{array}$ & $\begin{array}{l}\text { The difficulty of control is involved due to frictions and } \\
\text { interference of priorities between processes caused by the } \\
\text { sequence control between works and processes, construction } \\
\text { period, material amount fluctuation, frequent movement, and } \\
\text { weather changes, etc. }\end{array}$ \\
\hline Handling of many heavy weights. & $\begin{array}{l}\text { When handling and moving heavy weights, there is always a } \\
\text { main cause of serious accidents due to the excessive use of } \\
\text { heavy equipment. }\end{array}$ \\
\hline Very frequent manpower movement. & $\begin{array}{l}\text { It is a labor intensive industry, which manpower movement is } \\
\text { frequent due to the intensive manpower input of a unit project. }\end{array}$ \\
\hline The working environment is diversified. & $\begin{array}{l}\text { It is very difficult to respond to the working environment due to } \\
\text { diversification of the constructing ship types in the frequently } \\
\text { changed working environment. }\end{array}$ \\
\hline $\begin{array}{l}\text { The mixture of industries is inevitable within } \\
\text { a limited space. }\end{array}$ & $\begin{array}{l}\text { There is high probability of safety and health problems and } \\
\text { serious accidents occur due to an inseparable relation of frictions } \\
\text { or interferences between the work processes such as fire, } \\
\text { painting, outfit and hull welding works within the same space. }\end{array}$ \\
\hline
\end{tabular}

\subsection{Definition and Classification of Industrial Accidents}

Accidents, depending on the cause, can be classified into natural disasters and manmade disasters. According to the countermeasures against natural disasters act of Korea, a "disaster" is an accident arisen by a "typhoon, flood, heavy rain, strong wind, wind wave, tidal wave, tidewater, heavy snow, lightning strike, drought, earthquake (including tsunami), yellow dust and other equivalent natural phenomena". Formerly a "disaster" was defined an accident such as a "fire, collapse, explosion, traffic accident, chemical/biological/radiological accident, environmental pollution accident that could damage the people's lives and property", before the establishment of the current "framework act on disaster and safety control". In other words, damage caused by a natural disaster and an artificial cause is generally defined as a "disaster" and "accident", respectively [25].

In today's society, however, due to changes of various conditions such as economic development and diversification of social structure, the concept of a disaster is not limited only to natural phenomena any more as it was in the past, and scholars also use the term, disaster, mixed with ones such as accident, crisis, risk and danger [26,27].

Of them, according to the International Labor Organization (ILO), the "industrial accident" is defined as "bodily damage caused by doing work motions of workers like making contact with objects, materials or others", and in the industrial safety health act of Korea, it is defined as "workers are killed, injured or get a disease by work-related structures, equipment, raw materials, gas, steam, dust etc. or by works or other labors" [28,29].

\subsection{Status of Accidents by Process in the Shipbuilding Industry (Cases in Korea)}

The shipbuilding industry is an aggregate of a comprehensive technology such as mechanical, electrical and chemical, during which workers in various types of occupations carry out operations in an elevated place, carrying and handling of heavy weights, painting, and welding works all at the same time within a limited working space. Naturally, it is difficult to control the works and it could be considered that all the processes have great potential for the possibility of serious accidents such as fire or explosion.

Looking into the status of accidents processed in 2005, the processing/assembling, support part, and outfit process had 315 (28.6\%), 166 (15.1\%), and 145 (13\%) accidents, respectively, which account 
for $56.7 \%$ of the incidents that occurred, followed by accidents in painting and erection. Because these processes could not be automated due to the shipbuilding industry's features and most of the parent company's subcontractors, which safety control is relatively insufficient, put into the processes intensively, it was found that the accidents had occurred by unsafe worker behavior, noncompliance to standards of work safety practices, etc.

Other processes include work-assistance and preparation stage related to the ship construction process, or arrangement and organization excluding the ship construction process, which in total accounted for about $23.2 \%$ (in Table 3). It is considered that accidents have occurred due to the site facilities and insufficient safety measures for production support facilities that are relatively deteriorated compared to the ship process facilities.

Table 3. Status of Accidents by Process (Top 7 Shipyards, 2005).

\begin{tabular}{cccccccc}
\hline Total & $\begin{array}{c}\text { Processing/ } \\
\text { Assembly }\end{array}$ & Erection & Outfit & Painting & Support & $\begin{array}{c}\text { Inspection/ } \\
\text { Test }\end{array}$ & Others \\
\hline \multirow{2}{*}{1102} & 315 & 90 & 145 & 121 & 166 & 9 & 256 \\
& $(28.6 \%)$ & $(8.2 \%)$ & $(13.2 \%)$ & $(11.0 \%)$ & $(15.1 \%)$ & $(0.8 \%)$ & $(23.2 \%)$ \\
\hline
\end{tabular}

\subsection{Methodology of Designing u-Business Service Model}

Current Ubiquitous Technology is becoming increasingly advanced, but the level of development for an academic methodology to design and develop u-Business services using the technology remains insufficient. Specifically, the existing methodology related to designing and developing business services is limited to the traditional and e-business service areas; further studies on developing business service models that reflect the unique characteristics brought on by the Ubiquitous Computing environment are required.

This study therefore expands the existing methodology for e-business service development [30] to design a methodology for $\mathrm{u}$-Business service development that reflects characteristics of the Ubiquitous Computing environment, and was practically applied to verify the excellence of the methodology. The designed methodology for $\mathrm{u}$-Business services contains four main steps: (1) selecting applicable areas for u-Business services; (2) finding business opportunities in u-Business services; (3) designing and evaluating u-Business services; and (4) developing a u-Business model (Figures 2 and 3). It was organized to reflect the technical characteristics of Ubiquitous Computing and the u-Business paradigm at each step. Figure 4 shows the step-by-step process for a u-Business service design.

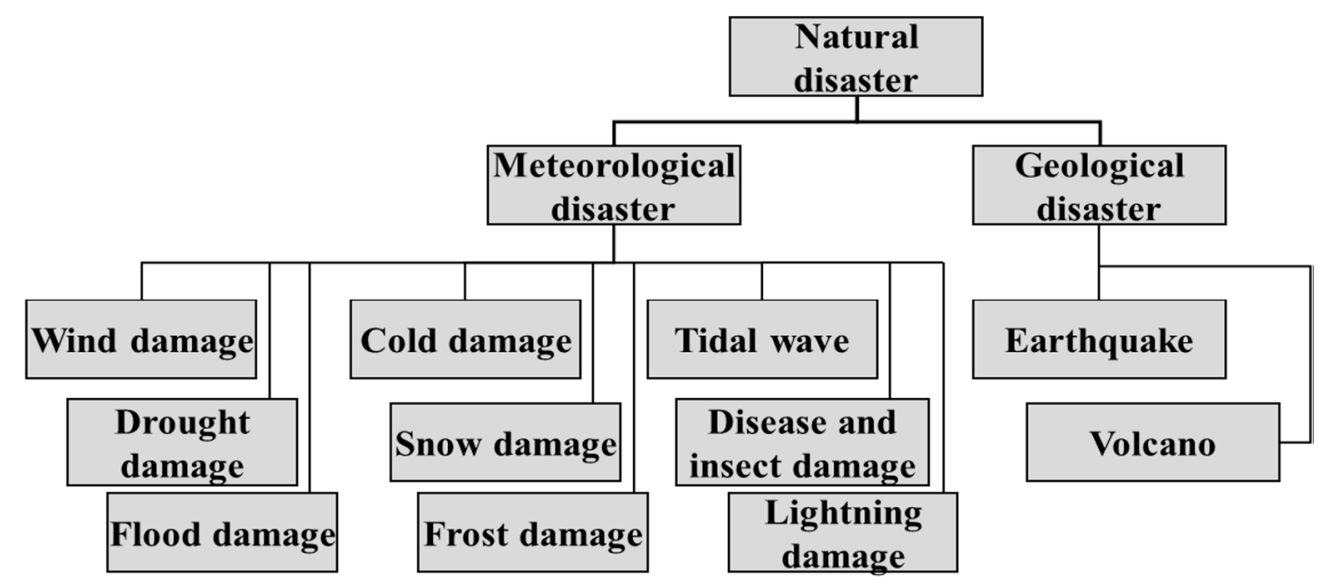

Figure 2. Classification of Natural Disasters. 


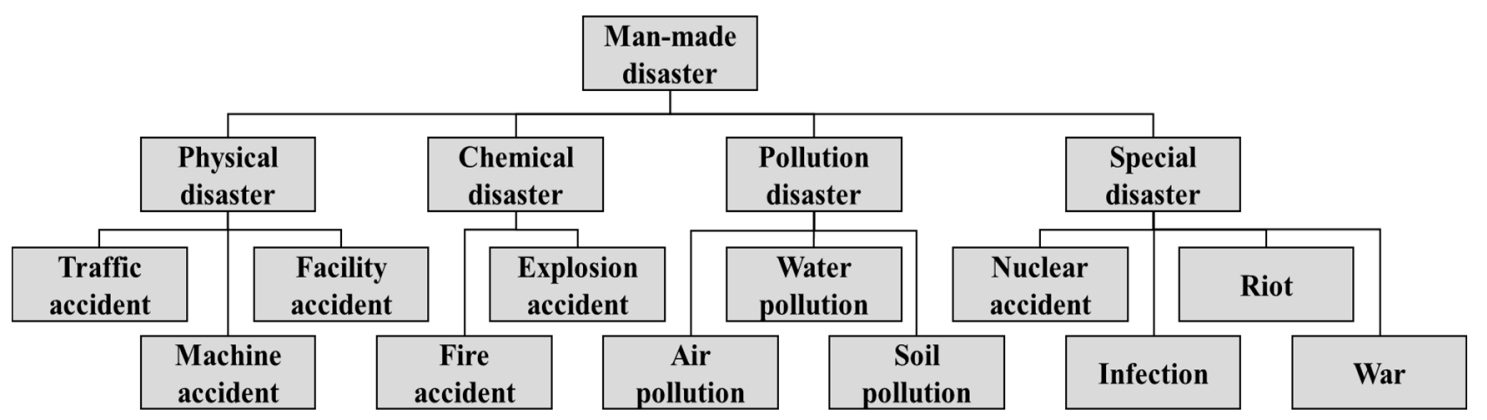

Figure 3. Classification of Man-made Disasters.

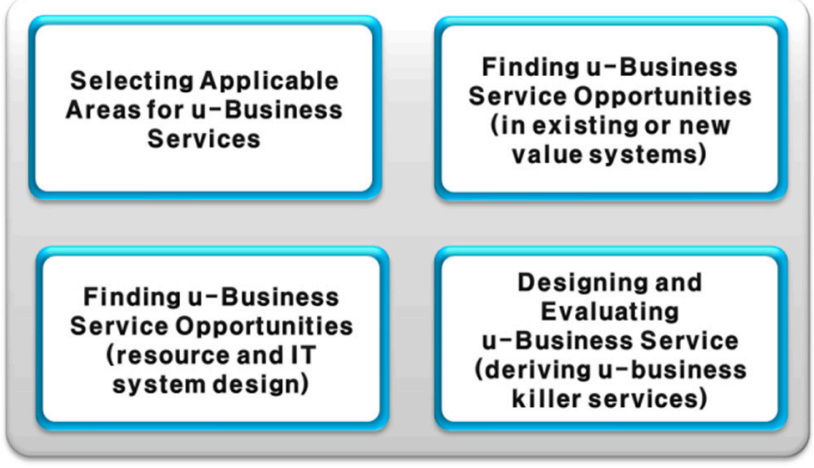

Figure 4. Methodology of Developing u-Business Service Model.

\section{Developing User-Centered u-Business Killer Services}

\subsection{Selecting Applicable Areas for u-Business Services}

\subsubsection{Shipbuilding Industry and Accidents}

Unlike other manufacturing businesses that conduct planned production (Make to Stock), the shipbuilding industry is an order (custom) production (Make to Order) industry that builds according to the ship owners' orders. Specifically, it performs small-quantity batch production, which has limitations in automated production; ship owners require various functions and forms of ships, and building process specifications vary for each production. Due to these characteristics, the shipbuilding industry is evaluated as an industry that has a large ripple effect on not only the upstream industries, including the shipping industry or fisheries, but also on downstream industries, including the steel, machinery, electrics, electronics, and chemical industries.

Although the shipbuilding industry is in an economically important position, the extent of industrial accident occurrences is at a more critical level than other manufacturing industries due to its labor-intensive industry characteristics, which make automated productions and mass production difficult. For instance, Korea's shipbuilding industry accident rate (the percentage of the number of casualties per 100 workers) was $1.08 \%$ in 2011, approximately 1.2 times higher the entire industrial accident rate $(0.87 \%)$. The resulting economic losses were reported to be $1.67 \%$ of the Gross Domestic Product (GDP), nearly five times the economic losses due to labor disputes. Thus, achieving sustainable development of the shipbuilding industry urgently requires establishing a plan to prevent or quickly respond to industrial accidents. Accordingly, this study analyzes the status of industrial accident occurrences following the general ship manufacturing process in the shipbuilding industry, and the $\mathrm{u}$-Business service design that utilizes the Ubiquitous Technology is performed to minimize such industrial accidents $[15,31]$. 


\subsubsection{Characterizing Accidents in the Shipbuilding Industry}

Various accidents occur according to the characteristics of shipbuilding process, which progresses in the following order: Block Assembly $\rightarrow$ Ship Outfitting $\rightarrow$ Painting $\rightarrow$ Erection. First, because workers frequently move around the shipbuilding job site, there are risks of temporary fixtures collapsing because of the workers' mistakes and of workers falling, particularly because the work takes on steel towers that are 2-10 $\mathrm{m}$ high. Moreover, there is always the danger of suffocation because the ship designs contain many sealed areas, and as the fire, painting, ship outfitting, and hull welding operations all proceed simultaneously in the same space, the conflicts between the work processes sometimes result in health and safety issues and a high probability of serious accidents. Finally, using significant heavy equipment to handle heavy objects always causes serious accidents. Because of the nature of these accidents, casualties and deaths in Korea's shipbuilding industry consistently occur at certain levels each year. The current status of Korea is indicated in Table 4.

Table 4. The Number of Casualties and Deaths in Korea's Shipbuilding Industry.

\begin{tabular}{cccccc}
\hline Classifications & $\mathbf{2 0 1 1}$ & $\mathbf{2 0 1 2}$ & $\mathbf{2 0 1 3}$ & $\mathbf{2 0 1 4}$ & $\mathbf{2 0 1 5}$ \\
\hline Number of Workers & 168,114 & 180,661 & 186,226 & 215,833 & 233,730 \\
Number of Casualties & 1820 & 1760 & 1596 & 1349 & 1940 \\
Number of Deaths & 46 & 51 & 37 & 37 & 31 \\
\hline
\end{tabular}

\subsection{Finding Business Opportunities from Existing or New Value System}

This study uses Ubiquitous Technology in the production process of the shipbuilding industry to first derive the types of industrial accidents that can be prevented or counteracted. Table 5 shows the types of shipbuilding industry accidents that were organized using references which collected the types of accidents that occurred on-site in the shipbuilding industry during the last three years, along with the knowledge of experts who work in shipyards. The information organized has served as the object of this study.

Table 5. Major Types of Disaster in Shipbuilding Industry.

\begin{tabular}{ll}
\hline Ship Manufacturing Process & Critical Types of Industrial Accidents \\
\hline Stowing and Pretreatment of Raw Materials & $\begin{array}{l}\text { Risk of collision between a vehicle and a worker } \\
\text { Risk of falling over or collapsing while unloading the steel materials }\end{array}$ \\
\hline Machine Cutting & $\begin{array}{l}\text { Risk of falling over while transferring the steel plate or a body part } \\
\text { getting caught during operation (Narrowness) }\end{array}$ \\
\hline Small/Medium Block Assembly & Risk of falling over when securing the vertical beams \\
\hline Painting & Risk of the blocks colliding with each other or falling over \\
\hline Ship Outfitting & Risk of suffocation during the painting process in a sealed space \\
\hline Erection & $\begin{array}{l}\text { Risk of fire while working wearing an air jacket with oxygen injection } \\
\text { Risk of falling when working on a high block }\end{array}$ \\
\hline Common & $\begin{array}{l}\text { Risk of dropping transporting materials due to defects in the shackles } \\
\text { and lugs connected to the crane } \\
\text { Risk of falling through openings such as manholes }\end{array}$ \\
\hline
\end{tabular}

\subsection{Designing and Evaluating the $u$-Business Service (Deriving $u$-Business Killer Services)}

Before utilizing Ubiquitous Technology to improve existing business services or develop new services, this study investigated the currently available services for industrial accident prevention and responses. An investigation found that services were being provided, including identifying the location of workers by attaching electronic tags to operators who work from high blocks, or detecting 
gas to prevent suffocation during the painting process in a sealed space. However, the effects of preventing industrial accidents were minimal. In this study, in-depth interviews with users of the shipbuilding industry (i.e., shipbuilding experts, site managers, and workers) were first conducted to derive the key causes (i.e., worker carelessness or equipment malfunction) for each type of shipbuilding industry accident. Thereafter, we took advantage of the currently developed Ubiquitous Component Technology to design u-Business services that can fundamentally prevent and respond to the accident types that occur in the shipbuilding industry, shown in Table 6. In detail, it first classified the accident types drawn from the earlier stage by major cause to draw candidate groups for $\mathrm{u}$-Business services. As a result, most of them were accidents by workers' carelessness, or otherwise, collapses, drop and constriction accidents of blocks, structural steel/members by defective parts, overload and incorrect fixation methods formed a large category. In an interview with the persons involved in the shipbuilding industry, it was also stated that most of accidents were caused by workers' carelessness and it is not so easy to prevent these accident risks with technologies in both an economic and an industrial relations' sense. Therefore, they said that it is necessary to develop technologies within the scope of being more economical and without affecting reliability of industrial relations. Furthermore, the greater part of current IT-like countermeasures are also services sensing and responding quickly to dangers such as fire/explosion/suffocation from a such standpoint, and some workplaces provide a service to locate through RFIDs only for workers working in an elevated space. The candidate groups of u-Business services were developed according to these facts and for each accident type drawn earlier.

Table 6. u-Business Service for Cause of Disaster in Shipping Industry.

\begin{tabular}{|c|c|}
\hline Critical Types of Industrial Accidents & $\begin{array}{l}\text { u-Business Services Designed for Industrial Accident } \\
\text { Prevention and Response }\end{array}$ \\
\hline $\begin{array}{l}\text { Risk of falling over or collapsing while unloading } \\
\text { steel materials }\end{array}$ & \multirow{2}{*}{$\begin{array}{l}\text { The weight of raw materials, movement angles, and line strengths are sensed } \\
\text { when transporting raw materials, and when they are greater than the permissible } \\
\text { range, workers are warned to stop working (S1) }\end{array}$} \\
\hline $\begin{array}{l}\text { Risk of falling over while transferring a steel plate or } \\
\text { a body part getting caught during operation } \\
\text { (Narrowness) }\end{array}$ & \\
\hline Risk of falling over when securing vertical beams & - \\
\hline $\begin{array}{l}\text { Risk of dropping transporting materials due to the } \\
\text { defects in shackles and lugs connected to the crane }\end{array}$ & $\begin{array}{l}\text { When monitoring the quality of components (degree of deterioration), the system } \\
\text { alerts a worker when he uses a component that goes beyond the permissible } \\
\text { range (S2) }\end{array}$ \\
\hline $\begin{array}{l}\text { Risk of the blocks colliding with each other or } \\
\text { falling over }\end{array}$ & - \\
\hline Risk of collision between a vehicle and a worker & $\begin{array}{l}\text { Recognize objects (people) that approach from behind using a smart camera } \\
\text { (sensor) and give a warning (S3) }\end{array}$ \\
\hline $\begin{array}{l}\text { Risk of falling when installing or disassembling } \\
\text { scaffoldings that are installed to allow working in } \\
\text { high places }\end{array}$ & \multirow{2}{*}{$\begin{array}{l}\text { Recognize those not wearing safety helmets (S4) } \\
\text { By using smart objects (helmet, glove, belt), recognize the: (1) } \\
\text { location/acceleration; (2) workers' stress and fatigue levels; and (3) unstable } \\
\text { posture of the workers to warn and respond (hospital service connection) (S5-S7) }\end{array}$} \\
\hline Risk of falling when working on a high block & \\
\hline Risk of falling through openings, including manholes & $\begin{array}{l}\text { Recognize sudden changes in a worker's location using smart objects and } \\
\text { respond quickly (S5) }\end{array}$ \\
\hline $\begin{array}{l}\text { Risk of fire while working, wearing the air jacket with } \\
\text { oxygen injection }\end{array}$ & $\begin{array}{l}\text { Warning by recognizing the oxygen concentration in the air jacket (S8) } \\
\text { Advance warning of accidents that occur frequently (S9) }\end{array}$ \\
\hline Risk of suffocation when painting in a sealed space & $\begin{array}{l}\text { Detect the oxygen and combustibility concentrations and illumination and } \\
\text { humidity intensities; when they are greater than the permissible range, notify the } \\
\text { entry way/nearby workers and automatically open or close the windows (S10) }\end{array}$ \\
\hline
\end{tabular}

For practical implementation, detailed service scenarios were created for the designed u-Business services, as in Table 7. The service scenarios created will be used as the basic materials for developing resources and information systems for future service development. 
Table 7. Extracted u-Business Service Scenario.

\begin{tabular}{|c|c|}
\hline Classification & u-Business Service Scenario \\
\hline S1 & $\begin{array}{l}\text { When transporting raw materials, the weight of the raw materials, swaying motion angle, } \\
\text { and line strength are recognized. If the recognized data are outside of the (safe) } \\
\text { permissible range, workers are warned to stop transporting the raw materials. }\end{array}$ \\
\hline S2 & $\begin{array}{l}\text { The quality (degree of deterioration) of the components is identified by recognizing the } \\
\text { degree of usage and wear. If the condition of the component used by the worker is outside } \\
\text { of the (safe) permissible range, the worker is notified to stop using the component. } \\
\text { Additionally, the number of deteriorated components is automatically determined so that } \\
\text { this information can be used when ordering the component from its suppliers in the future. }\end{array}$ \\
\hline S3 & $\begin{array}{l}\text { Smart sensors are mounted on the back of the vehicles (truck, forklifts, or excavators). The } \\
\text { mounted smart sensors notify the driver and stop the vehicle when a person approaches } \\
\text { within a certain distance while driving the vehicle. }\end{array}$ \\
\hline $\mathrm{S} 4$ & $\begin{array}{l}\text { Smart cameras installed at the construction site automatically recognize people not } \\
\text { wearing (yellow) safety helmets, zoom in to photograph, and send the person's location } \\
\text { and photo to the integrated control center, as well as use the nearby speaker to warn the } \\
\text { worker to wear the helmet. }\end{array}$ \\
\hline S5 & $\begin{array}{l}\text { When a hazardous situation (fire, explosion, or fallen worker) occurs near the workers, the } \\
\text { smart helmet immediately recognizes this and notifies workers and the integrated control } \\
\text { server. This provides a quick response in an emergency situation by notifying the nearby } \\
\text { workers and giving instructions for handling the accident or giving the location of fire } \\
\text { extinguishers and emergency exits through the smart helmets. }\end{array}$ \\
\hline S6 & $\begin{array}{l}\text { Measure the stress levels of workers before starting work (or on a regular basis). If that } \\
\text { level is outside of the permissible range or deviates greatly from the worker's normal } \\
\text { levels, it is recommend that the worker take a break. When the stress level is serious, take } \\
\text { responsive actions, including contacting the emergency center at local hospitals. }\end{array}$ \\
\hline S7 & $\begin{array}{l}\text { Workers who work on high blocks are to wear smart gloves at all times. The smart gloves } \\
\text { recognize when the worker exhibits careless (unsafe) behavior/posture (for example, } \\
\text { working while holding heavy equipment in both hands) and notify the worker and the } \\
\text { integrated control center. }\end{array}$ \\
\hline S8 & $\begin{array}{l}\text { Automatically recognize the oxygen and flammable gas concentrations in the air jacket to } \\
\text { automatically shut off the gas supply device and prevent the worker from inhaling the } \\
\text { wrong type of gas. }\end{array}$ \\
\hline S9 & $\begin{array}{l}\text { Gather data about the situations (time period, location, or work contents) in which } \\
\text { accidents occur. Based on the collected data, safety warnings are provided to workers in } \\
\text { advance for the accident-prone work situations. }\end{array}$ \\
\hline S10 & $\begin{array}{l}\text { Recognize the flammable gas and oxygen concentrations, temperature, humidity, and } \\
\text { illumination in the enclosed space, indicate warning light/warning signs at the entryway, } \\
\text { and automatically open the window when outside the permissible range. The smart } \\
\text { cameras installed in the workspace detect fires and notify the integrated control center } \\
\text { when there is a fire by sending a video of it. The integrated control center responds by } \\
\text { transferring the facts about the fire to the nearby hazard facility to take safety measures } \\
\text { and contacts the fire department when necessary. }\end{array}$ \\
\hline
\end{tabular}

The shipbuilding industry user evaluation of the designed U-Business services included three types of evaluation items, service usability, reliability, and versatility and extensibility, based on previous studies [32]. Evaluation items and the designed U-Business service scenarios were explained directly to the respondents, and their questionnaire evaluations (seven-point scale) were conducted. The surveys were collected from 1 September 2009 to 20 November 2009 and received responses from 32 companies in the ship manufacturing business. To validate the collected survey results, a multivariate analysis was performed, as in Table 8 , and statistically significant differences were found between the u-Business services according to the evaluation items $(p<0.05)$. 
Table 8. Reliability Test Results of Proposed u-Business Services (Multivariate Test).

\begin{tabular}{ccccccc}
\hline Effect & Value & F & $\begin{array}{c}\text { Hypothesis } \\
\text { Degree of } \\
\text { Freedom }\end{array}$ & $\begin{array}{c}\text { Error } \\
\text { Degree of } \\
\text { Freedom }\end{array}$ & $p$-Value \\
\hline \multirow{3}{*}{ Intercept } & Trace of Pillai & 0.929 & $599.852(\mathrm{a})$ & 3.000 & 137.000 & 0.000 \\
& Intercept Lambda of Wilks & 0.071 & $599.852(\mathrm{a})$ & 3.000 & 137.000 & 0.000 \\
& Trace of Hotelling & 13.135 & $599.852(\mathrm{a})$ & 3.000 & 137.000 & 0.000 \\
& Max Val. of Roy & 13.135 & $599.852(\mathrm{a})$ & 3.000 & 137.000 & 0.000 \\
\hline \multirow{5}{*}{ Service } & Trace of Pillai & 0.339 & 1.967 & 27.000 & 417.000 & 0.003 \\
& Service Lambda of Wilks & 0.684 & $2.061(\mathrm{a})$ & 27.000 & 400.753 & 0.002 \\
& Trace of Hotelling & 0.429 & 2.155 & 27.000 & 407.000 & 0.001 \\
& Max Val. of Roy & 0.339 & $5.236(\mathrm{~b})$ & 9.000 & 139.000 & 0.000 \\
\hline
\end{tabular}

a. Accurate statistics; $b$. Statistics that cause the lower limit in the corresponding level of significance to be the upper limit in $\mathrm{F}$.

Based on the significant statistical analysis results, as in Table 9, the arithmetic mean of the evaluation scores for each $\mathrm{u}$-Business service were calculated, and the priority order was set between the u-Business services, as in Table 9. As a result, a service to prevent the accidents caused by defective components by recognizing the component usage and the degree of deterioration (S2), a service to prevent accidents by recognizing the workers' stress levels (S6), a prior warning service based on the collected data about the circumstances of the accidents (S9), and an accident prevention and response service using the smart sensor and smart objects (helmet) (S5) were derived as killer services.

Table 9. Evaluation Results of Extracted u-Business Services.

\begin{tabular}{cccccc}
\hline Service & Usability & Reliability & $\begin{array}{c}\text { Versatility and } \\
\text { Extensibility }\end{array}$ & Total & Ranking \\
\hline S1 & 4467 & 4200 & 4533 & 4400 & 7 \\
S2 & 6200 & 6067 & 4333 & 5533 & 1 \\
S3 & 4600 & 4133 & 4467 & 4400 & 7 \\
S4 & 3667 & 3533 & 3467 & 3556 & 10 \\
S5 & 4800 & 4733 & 4733 & 4756 & 4 \\
S6 & 5267 & 5133 & 4933 & 5111 & 2 \\
S7 & 4571 & 4643 & 4571 & 4595 & 5 \\
S8 & 4067 & 4067 & 4133 & 4089 & 9 \\
S9 & 5133 & 4867 & 4667 & 4889 & 3 \\
S10 & 4667 & 4467 & 4200 & 4444 & 6 \\
\hline
\end{tabular}

\subsection{Developing a u-Business Killer Service Model (Designing Resource and IT Systems)}

\subsubsection{Value Proposition for $\mathrm{u}$-Business Killer Services}

For the selected killer service, the value proposition process of u-Business killer service refers to: (1) selecting the target market (target customer); (2) selecting the core benefits to be provided to the customers; and (3) defining the unique and distinctive capabilities for providing outstanding benefits compared to other competing companies.

The target customers in this study are shipbuilding companies, and the focal customer benefits include: (1) providing a safe working environment through advance warning for accident prevention; and (2) minimizing damage by quickly recognizing and taking actions for abnormal workplace environments. By giving a warning of possible accident occurrence in advance based on data collected for the accident context occurred in the site, workers' awareness of safety could be promoted to prevent accidents caused by carelessness, making it so that the collected data are used to establish a safe work procedure. Furthermore, by immediately recognizing the occurrence of abnormal environments (accidents) through various sensors and giving a warning directly to workers as well as workplaces, it could quickly and efficiently respond to them. 
In contrast to most IT services provided for preventing accidents in the shipbuilding industry that focus on responding to fire and explosion accidents, the u-Business killer services derived from this study can be applied to prevent general industrial accidents, including collision and falling accidents. In addition, considering the characteristics of the ship manufacturing environment, in which oxygen and flammable gases are always present due to operations such as welding and painting, current countermeasures that only determine the present oxygen and flammable gasses are ineffective. This study thus also measures sensor information, including video and audio data, to recognize accident circumstances.

\subsubsection{Definition of Providing u-Business Killer Services}

When developing the existing -business services, the services were designed according to the customer's decision-making process. In this study, the services were designed whenever various industrial accidents occurred for the workers who perform specific tasks. Figure 5 shows the designed services that can be provided to workers who are responsible for welding the blocks.

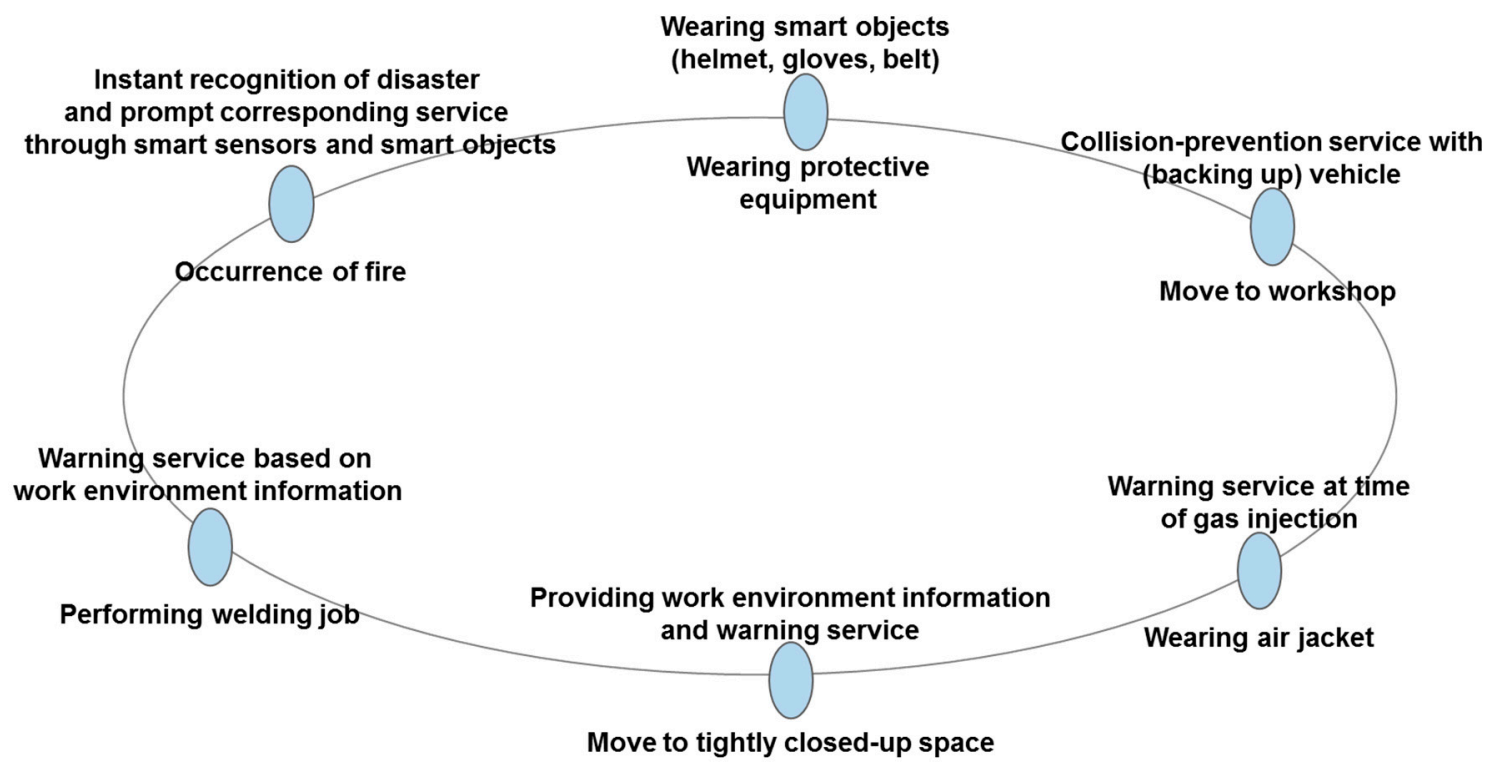

Figure 5. u-Business Service Components (in the Case of Welding/Finishing worker).

\subsubsection{Designing the Resource System for a u-Business Killer Service}

To provide customers with core benefits of value propositions, such as minimizing damage by immediately recognizing the abnormal workplace environments and quickly taking action and providing a safe working environment through advance warning for accident prevention, a system should include: (1) the ability to collect data on various accident circumstances and recognize situations; (2) the ability to organize a dynamic community; (3) the ability to accurately analyze accident circumstances; (4) the ability to prevent accidents and deliver accidence occurrence warnings, and (5) the system quickly responding to accidents.

With the ability to collect data on various circumstances of accidents and recognize the situation, several different sensors collect the situation data, which are comprehensively analyzed to accurately determine the accidents that occur at the shipbuilding work site. The ability to organize a dynamic community allows for the compilation of more accurate data on the situation or appropriate advance warnings or responses to the analyzed accidents. The ability to accurately analyze the circumstances of accidents allows for accurately analyzing the type of industrial accident in which a given occurred accident belongs to. With the ability to prevent accidents and deliver occurrence warnings, the advance or occurrence warnings are effectively communicated to the workers according to the organized 
community. Finally, the system to quickly respond to accidents provides effective services through the integrated control center located in the shipyard and its own fire department, as well as through connections with nearby disaster response facilities (fire departments or hospitals).

Resources according to the key benefits and capabilities are smart objects, smart centers (nodes), accident context recognition algorithms, accident context database, accident context analysis/inference algorithms (types classification), service templates, simulators, member management, warning delivery devices, integrated control center, connection with nearby organizations (fire stations and hospitals), etc. (in Figure 6).

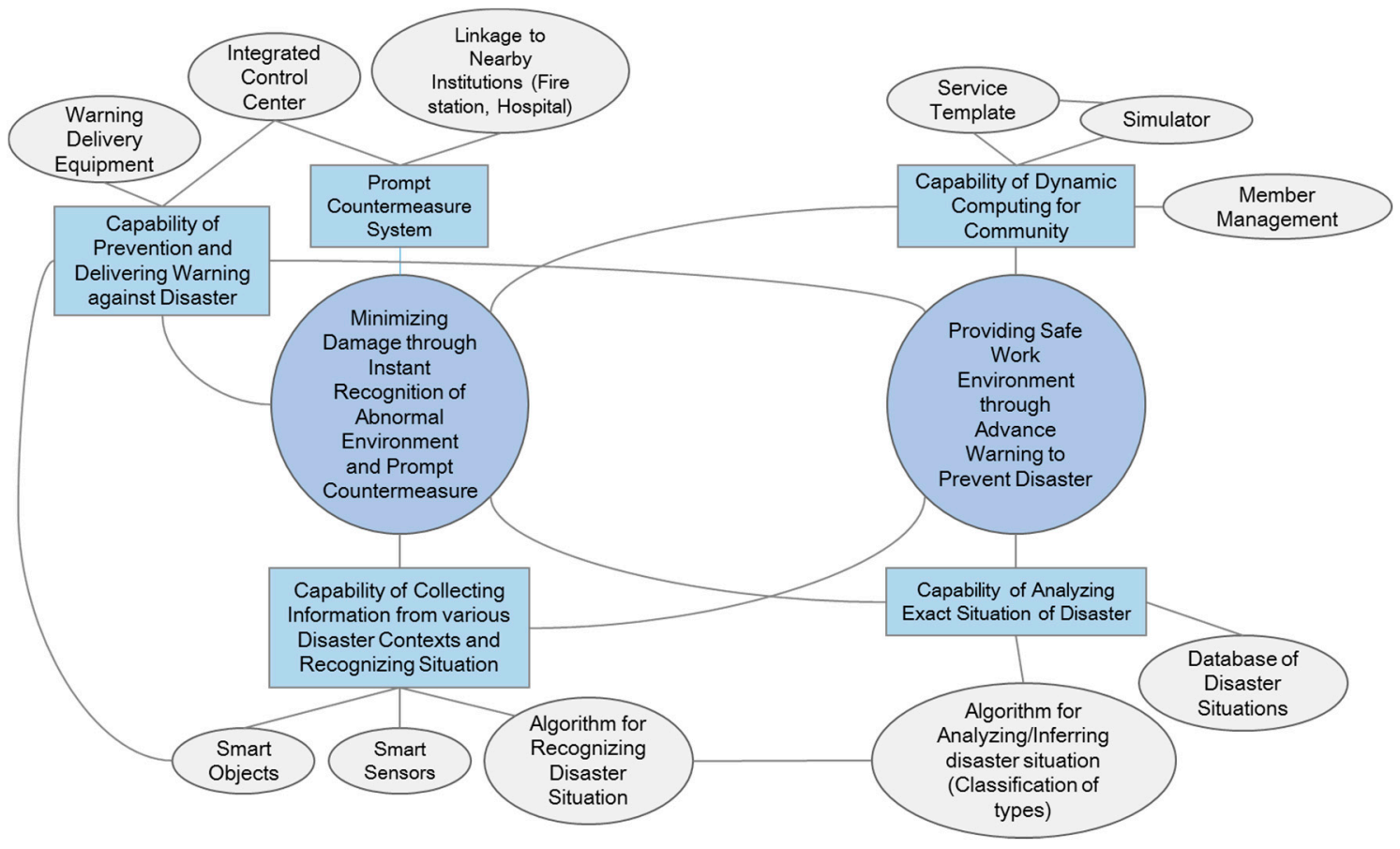

Figure 6. u-Business Service Resource Map.

The smart objects function as follows. They add sensing and alarm functions to helmets, belts, gloves, etc. worn by workers. They could sense various environmental data (temperature, humidity, illumination, current, images, and acceleration), recognize movements, positions and actions of workers using them, and output events (vibration, alarm and LED) according to dangerous situations. Furthermore, they could send information about major accident contexts (video on fire, etc.) to an integrated control center via a PAN or the existing wireless network, and additionally provide a function of sharing danger alarms between smart objects.

The smart sensors (nodes) function as follows. The accident context information is collected from the fixed sensors installed in a workplace in the form of images, acoustics (voice) and various environmental information (PIR, gas, temperature, humidity, illumination, etc.) sensors, and the collected information is comprehensively organized to provide a quick and accurate context recognition function in the site. If necessary, a sensor node playing the role of the gateway could be placed separately to secondarily recognize contexts to lower the false rate about accident occurrence. The smart camera could additionally recognize objects (persons, animals, and vehicles) and search images based on their content.

The accident context recognition algorithm has the following functions. It is an algorithm that comprehensively analyzes information collected from smart sensors (nodes) and smart objects to recognize contexts and types of accidents currently occurred. Managers could also specify a rule separately for recognizing accident contexts. 
The accident context database has the following functions. It stores the context information related to the accident occurred into the database.

The accident context analysis/inference algorithm (type classification) has the following functions. It analyzes the stored accident context information to infer possible contexts. Managers could also specify the context for possible accidents as a separate rule based on the previous experiences.

The service template has the following functions. The service templates (definition of situations, goals, roles and procedures) should be specified in advance for sensing context information according to the request of applications (integrated control center, etc.) or for appropriate prior warnings and response services against the analyzed accident types. The specified templates should be established appropriately in the context information recognition and warning/response services.

The simulator has the following functions. By supporting the add, delete and deploy functions of users, devices and services and the community simulation function in a virtual space, it enables to design efficient templates.

The member management has the following functions. A member is a basic component consisting of the community computing system, which computing devices, hardware, persons or services representing software, etc. belong to, and is implemented as an agent or service. When a particular goal takes place to construct a community, a member belonged to the community plays its own role for accomplishing the goal. At this time, the overall management such as the location change of members, out of control conditions and understanding of collision between members should be carried out for the members.

The warning delivery device has the following functions. When an accident or a situation of possible accident occurs, it should issue appropriate warnings (announcement, message service, warning sound, warning message, etc.). At this time, the warning could be delivered directly to workers through smart objects that they wear as well as through the workplace. It enables the integrated control center to identify the warning in real time through a popup screen or text message to the manager besides the actual announcement and warning sound, and a video would also be sent out if necessary.

The integrated control center has the following function. It is an integrated organization that exercises controls in relation to accidents occurring in the workplace, making a connection with nearby organizations (fire station, hospital, etc.) based on the collected accident context data in order to minimize the damage. It additionally establishes a rule suitable for the situation based on the collected data to constantly improve and manage circumstances.

The connection with nearby organizations (fire station, hospital) has the following functions. When a serious accident such as a fire, explosion and fall occurs, the connection enables quick response through the connection with nearby organization.

\subsubsection{Designing a U-Business Killer Service IT System}

To actually implement the $u$-Business killer services derived earlier, the killer service IT system shown in Figure 7 was organized based on previous studies on Ubiquitous Component Technologies. 


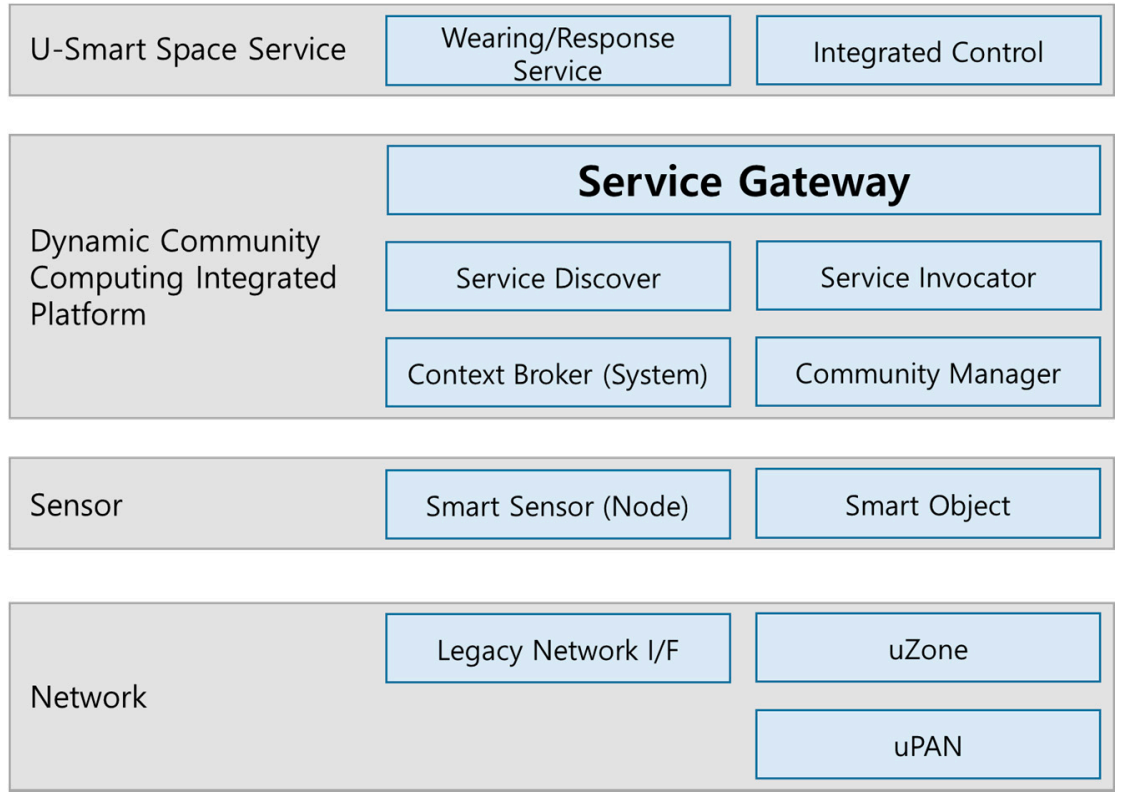

Figure 7. U-Business Killer Service IT system.

- Scale-free uPAN: The WPAN (Wireless Personal Area Network) such as Bluetooth, Zigbee and UWB is often used as a Ubiquitous Computing network. For the WPAN, one of the high rate WPAN and the low rate WPAN is generally used according to the supporting distance, speed, power and lightweight degree required for providing services. The technology used here is a scale-free uPAN that recognizes various environment variables such as the object position, channel condition, type of data transmitted to serve self-regulated varying data transfer rate (from the minimum $20 \mathrm{kbps}$ to the maximum $1 \mathrm{gbps})$.

- uZone: It is a network technology to support an intelligent ubiquitous space based on the community computing, which enables the converged intelligent network service.

- Smart Object: It is that a sensing and alarm function is added to helmets, belts, gloves, etc. worn by workers in Figure 8. It can sense a variety of environmental data (temperature, humidity, illumination, current, image, and acceleration), recognize movements, positions and actions of workers, and generate an event (vibration, alarm and LED) depending on whether there is a dangerous situation. It can also send information on major emergency situations (video about a fire, etc.) to the integrated control center via a PAN or the existing wireless network, and additionally provide a danger alarm sharing functions between smart objects.

\begin{tabular}{|c|c|c|}
\hline $\begin{array}{l}\text { Temp/Hum } \\
\text { Sensor }\end{array}$ & $\begin{array}{l}\text { Camera } \\
\text { Module }\end{array}$ & \\
\hline Acc Sensor & $\begin{array}{c}\text { Micro } \\
\text { Control } \\
\text { Unit }\end{array}$ & $\begin{array}{c}\text { RF } \\
\text { Transceiver }\end{array}$ \\
\hline $\begin{array}{l}\text { Vibration } \\
\text { Voice, LED }\end{array}$ & $\begin{array}{c}\text { Vibration } \\
\text { Voice, LED }\end{array}$ & $\begin{array}{l}\text { Power } \\
\text { Supply }\end{array}$ \\
\hline
\end{tabular}

Figure 8. Components of the Smart Object. 
- Context broker (system): It operates as the event-condition-action method, which delivers context information to applications if there is a matched rule after comparing the occurred context information with the rules registered by the applications (integrated control center, etc.) in Figures 9 and 10. Conversely, it plays a role in providing the corresponding context information delivered from the sensor when applications inquire the context information.

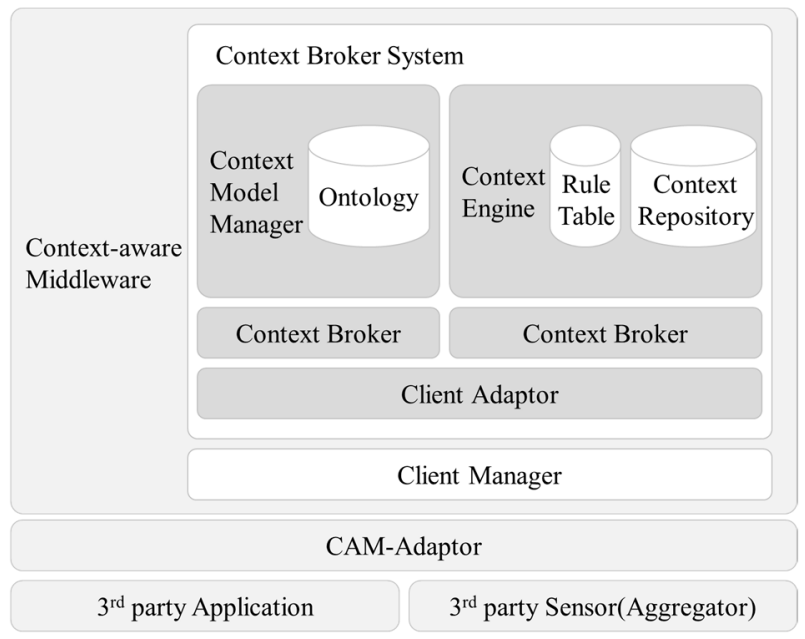

Figure 9. Components of the Context Broker.

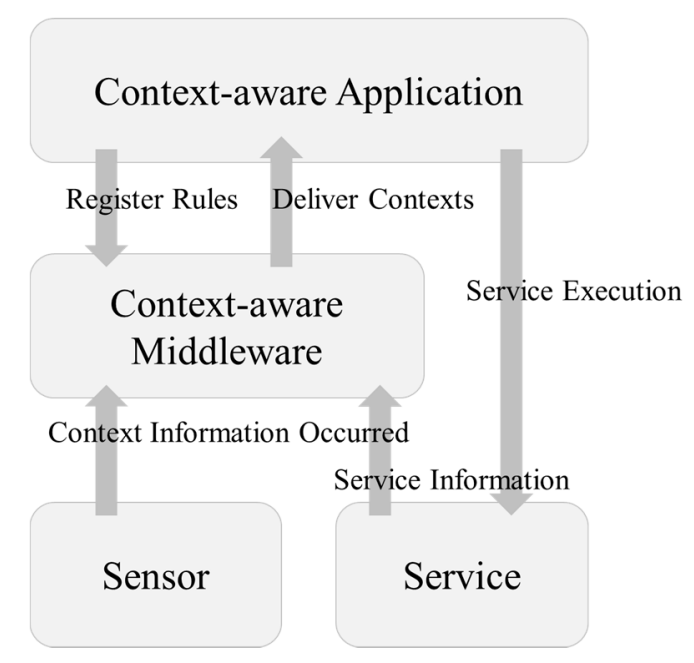

Figure 10. A Process Flow between the Context Broker and Other Modules.

- Community manager: It supports dynamic community computing, which is composed of a community editor to support a design of service templates (definition of situations, goals, roles and procedures) through a community model, a community manager to dynamically select member services to construct a community according to the actual run time, and a USS simulator to provide the community service simulation support and member add/delete/deploy functions in a virtual space and interworking functions between context brokers and community managers in Figure 11. 


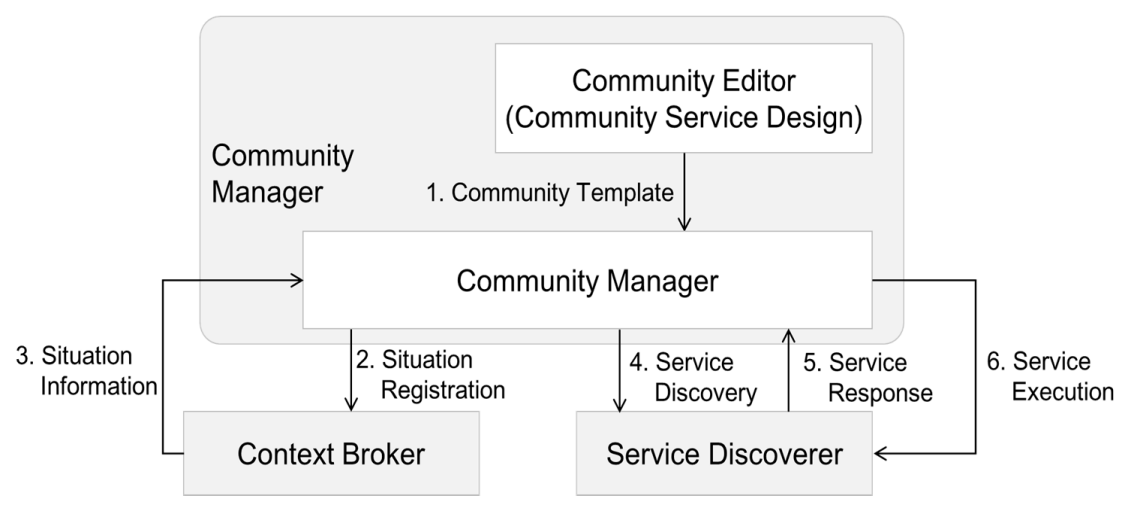

Figure 11. A Process Flow between the Context Manager and Other Modules.

- Service Discoverer: Repository where certain situation data and the corresponding services are connected

Using these Ubiquitous Component Technology functions, Figure 12 summarizes the overall service behavior scenarios, in terms of preventing and responding to industrial accidents that occur in the shipbuilding industry site. Accordingly, the previously derived u-Business killer services also have the following basic IT system organization.

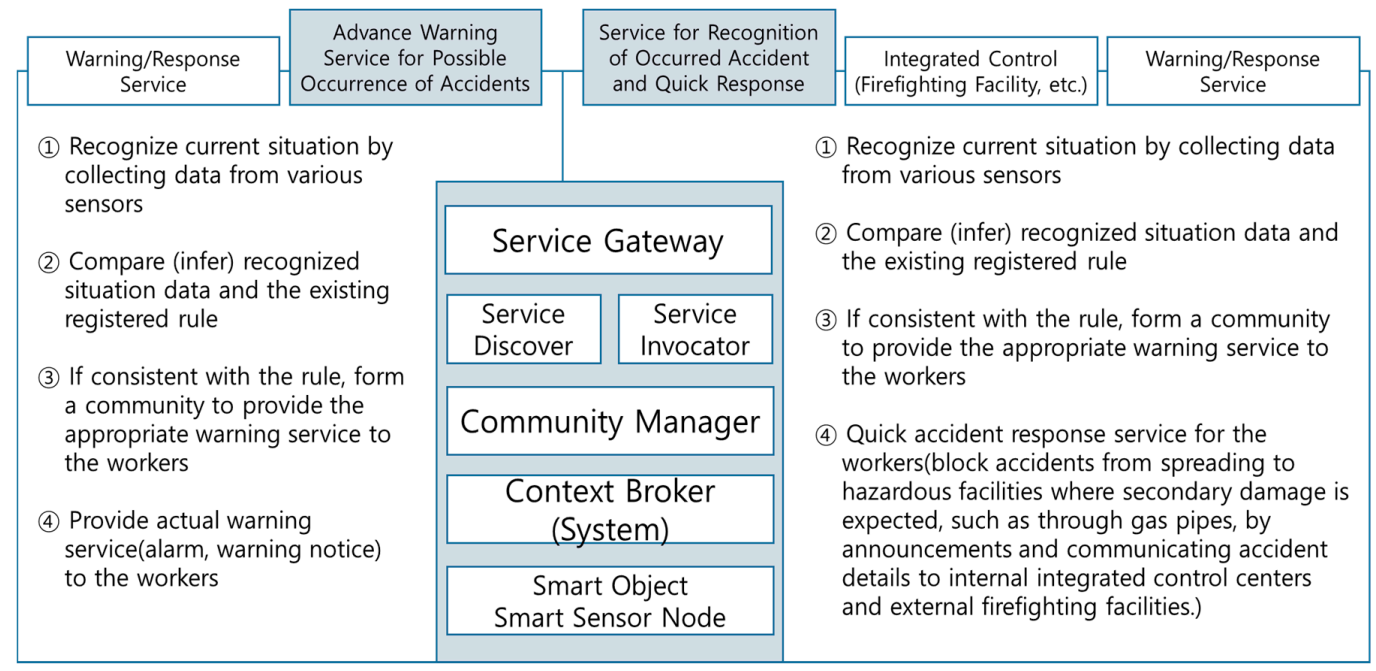

Figure 12. Resource Map for u-Business Service.

\section{Conclusions and Future Study}

This study improved the existing methodology for e-business service development to design a methodology for a u-Business service development that reflects the characteristics of Ubiquitous Computing. To verify the developed methodology, the service user (consumer)-centered U-Business services were developed for industrial accident prevention and response in the shipbuilding industry, where the number of accidents and degree of disasters that occur have recently been severe. The user requirements were collected from current shipbuilding industry sites (business process), and $\mathrm{u}$-Business services were designed to address the collected requirements. After evaluating the designed $\mathrm{u}$-Business services in various aspects, the final $\mathrm{u}$-Business killer services were derived. Finally, the resource map and IT system for the actual u-Business killer service implementation were designed. The research derived the following final killer services: the service to prevent accidents caused by defective components by recognizing component usage and the degree of deterioration, 
the service to prevent accidents by recognizing the workers' stress levels, prior warning service based on the collected data about accident circumstances, and the accident prevention and response service using the smart sensor and smart objects (helmet).

This type of study breaks away from the technology-centered business service development method, which organizes business services by simply combining the technologies that are developed (or that are to be developed in the future). Rather, this type of study can be summarized as a user-centered business service development method, which designs business services by collecting and analyzing the requirements perceived by users of the current value system.

The user-centered development approach for $\mathrm{u}$-Business services is expected to contribute to the creation of trapped and new values, using Ubiquitous Component Technology to solve the unmet and underserved needs currently experienced by the users. Furthermore, because the u-Business killer services derived in this study have a high probability of actual implementation using the currently developed (to be developed in the near future) Ubiquitous Technology, this study gains additional meaning. Finally, the method for first designing the necessary u-Business service and then presenting the development requirements for Ubiquitous Technology is expected to provide the foundations for u-Business service diffusion and to present its validity for technological development.

In the future, it will be necessary to verify the validity of this methodology more precisely by applying the u-Business service development methodology to a variety of industries. Furthermore, comprehensive research on the additionally required laws, standardization of the technology and services, and security is necessary so that the implemented u-Business services become successful after commercialization and not just remain at the pilot project level.

Acknowledgments: This work was supported by Institute for Information \& communications Technology Promotion (IITP) grant funded by the Korea government (MSIP) (H8501-17-1018).

Author Contributions: Taehee Joe coordinated, processed the data, and generated the results of the work. Taehee Joe then coordinated the writing of the manuscript, and contributed to the text. Hangbae Chang conceived and supervised the work.

Conflicts of Interest: The authors declare no conflict of interest.

\section{References}

1. Petrova, K.; Wang, B. Location-based services deployment and demand: A roadmap model. Electron. Commer. Res. 2011, 11, 5-29. [CrossRef]

2. Hallsteinsen, S.; Geihs, K.; Paspallis, N.; Eliassen, F.; Horn, G.; Lorenzo, J.; Mamelli, A.; Papadopoulos, G.A. A development framework and methodology for self-adapting applications in ubiquitous computing environments. J. Syst. Softw. 2012, 85, 2840-2859. [CrossRef]

3. Qiao, X.-Q.; Li, X.-F.; Liang, S.-Q. Reference model of future ubiquitous convergent network and context-aware telecommunication service platform. J. China Univ. Posts Telecommun. 2006, 13, 50-56. [CrossRef]

4. Kwon, O.; Yoo, K.; Suh, E. UbiDSS: A proactive intelligent decision support system as an expert system deploying ubiquitous computing technologies. Expert Syst. Appl. 2005, 28, 149-161. [CrossRef]

5. Lee, S.; Kim, H.J.; Kwon, O.B. A study on the Multidimensional Service Scenario Evaluation Methodology for ITSM Construction Considering Ubiquitous Computing Technology. J. Soc. e-Bus. Stud. 2007, 12, 155-194.

6. Klein, H.J. Shipbuilding trends in response to environmental issues. WMU J. Marit. Aff. 2007, 6, 167-175. [CrossRef]

7. Borrajo, M.L.; Corchado, J.M.; Corchado, E.S.; Pellicer, M.A.; Bajo, J. Multi-agent neural business control system. Inform. Sci. 2010, 180, 799-1074.

8. Asheim, B.T.; Isaksen, A. Regional Innovation Systems: The Integration of Local 'Sticky' and Global 'Ubiquitous' Knowledge. J. Technol. Transf. 2002, 27, 77-86. [CrossRef]

9. Chang, H.; Kang, J.; Kim, Y.; Lim, J.; Na, Y. A Case Study on Cooperative Real-time Quality Monitoring Service Utilizing Sensor Networks. In Computer Science and Convergence; Lecture Notes in Electrical Engineering; Springer: Dordrecht, The Netherlands, 2012; pp. 203-210. 
10. Moschetta, E.; Antunes, R.S.; Barcellos, M.P. Flexible and secure service discovery in ubiquitous computing. J. Netw. Comput. Appl. 2010, 33, 128-140. [CrossRef]

11. Taylor, D.G.; Davis, D.F.; Jillapalli, R. Privacy concern and online personalization: The moderating effects of information control and compensation. Electron. Commer. Res. 2009, 9, 203-223. [CrossRef]

12. Yu, X.-Y.; Lin, R.-H.; Huang, P.-C. Research of a Ubiquitous-Computing Enabled Service Pattern in Converged Network. Adv. Intell. Soft Comput. 2012, 143, 715-722.

13. Nylander, S.; Bylund, M.; Waern, A. Ubiquitous service access through adapted user interfaces on multiple devices. Pers. Ubiquitous Comput. 2005, 9, 123-133. [CrossRef]

14. Baousis, V.A.; Kyriakakos, M.; Hadjiefthymiades, S.; Merakos, L. A Multiagent Platform for Ubiquitous Service Provision. J. Netw. Syst. Manag. 2009, 17, 371-396. [CrossRef]

15. Baruque, B.; Corchado, E.; Mata, A.; Corchado, J.M. A forecasting solution to the oil spill problem based on a hybrid intelligent system. Inf. Sci. 2010, 180, 2029-2043. [CrossRef]

16. Chua, H.-C.; Hwanga, G.-J.; Tsaib, C.-C. A knowledge engineering approach to developing mindtools for context-aware ubiquitous learning. Comput. Educ. 2010, 54, 289-297. [CrossRef]

17. Petric, A.; Trzec, K.; Jurasovic, K.; Podobnik, V.; Jezic, G.; Kusek, M.; Ljubi, I. Agent-Based Support for Context-Aware Provisioning of IMS-Enabled Ubiquitous Services. In International Workshop on Service-Oriented Computing: Agents, Semantics, and Engineering; Springer: Berlin/Heidelberg, Germany, 2009; pp. 71-82.

18. Lin, C.-C.; Lee, R.-G.; Hsiao, C.-C. A pervasive health monitoring service system based on ubiquitous network technology. Int. J. Med. Inform. 2008, 77, 461-469. [CrossRef] [PubMed]

19. Hu, C.-L.; Cho, C.-A. User-provided multimedia content distribution architecture in mobile and ubiquitous communication networks. J. Netw. Comput. Appl. 2011, 34, 121-136. [CrossRef]

20. Eurich, M.; Oertel, N.; Boutellier, R. The impact of perceived privacy risks on organizations' willingness to share item-level event data across the supply chain. Electron. Commer. Res. 2010, 10, 423-440. [CrossRef]

21. Su, W.-T.; Kuo, Y.-H.; Huang, P.-C. A QoS-driven approach for service-oriented device anycasting in ubiquitous environments. Comput. Netw. 2008, 52, 3342-3357. [CrossRef]

22. Cai, H.; Hu, X.; Lü, Q.; Cao, Q. A novel intelligent service selection algorithm and application for ubiquitous web services environment. Expert Syst. Appl. 2009, 36, 2200-2212. [CrossRef]

23. Son, S.H.; Bae, S.M. Dissemination of Production Technology Using Manufacturing Knowledge Sharing Platform System. Adv. Sci. Lett. 2012, 13, 332-338. [CrossRef]

24. Lian, S. Innovative Internet video consuming based on media analysis techniques. Electron. Commer. Res. 2011, 11, 75-89. [CrossRef]

25. Zhou, B.; Shi, Q.; Merabti, M. Balancing intrusion detection resources in ubiquitous computing networks. Comput. Commun. 2008, 31, 3643-3653. [CrossRef]

26. Leung, A.; Sheng, Y.; Cruickshank, H. The security challenges for mobile ubiquitous. Inf. Secur. Tech. Rep. 2007, 12, 162-171. [CrossRef]

27. Liu, Q.; Gao, F. Context-aware location discovery exchange in a ubiquitous environment. J. China Univ. Posts Telecommun. 2012, 19, 73-78. [CrossRef]

28. Dong, H.; Hussain, F.K.; Chang, E. A framework for discovering and classifying ubiquitous services in digital health ecosystems. J. Comput. Syst. Sci. 2011, 77, 687-704. [CrossRef]

29. Su, S.Y.W.; Meng, J.; Krithivasan, R.; Degwekar, S.; Helal, S. Dynamic Inter-Enterprise Workflow Management in a Constraint-Based E-Service Infrastructure. Electron. Commer. Res. 2003, 3, 9-24. [CrossRef]

30. Rayport, J.; Jaworski, B. Introduction to E-Commerce; McGraw-Hill Inc.: New York, NY, USA, 2003.

31. Cao, L. In-depth behavior understanding and use: The behavior informatics approach. Inform. Sci. 2010, 180, 3067-3380. [CrossRef]

32. Qin Shiming, S.D.; Wang, G.-N. Interactive Genetic Algorithms for Optimal Assignment of Blocks into Workspaces of Shipbuilding Industry. Int. J. Appl. Evolut. Comput. 2016, 6, 19. [CrossRef]

(C) 2017 by the authors. Licensee MDPI, Basel, Switzerland. This article is an open access article distributed under the terms and conditions of the Creative Commons Attribution (CC BY) license (http:/ / creativecommons.org/licenses/by/4.0/). 